UDC 624.016:69.059:624.014:69.05

\title{
INVESTIGATION OF THE EFFECTIVENESS OF STRENGTHENING WITH FRP APPLIED IN METAL ELEMENTS OF SUSPENSION ROOF: AN ANALYTICAL APPROACH
}

\author{
I.M. Rudnieva ${ }^{1}$, \\ $\mathrm{PhD}$, Associate Professor \\ Y.M. Priadko ${ }^{2}$, \\ $\mathrm{PhD}$, Associate Professor \\ H.M. Tonkacheiev ${ }^{1}$, \\ Doctor of Technical Sciences, Professor \\ M.V. Priadko ${ }^{3}$, \\ $\mathrm{PhD}$, Associate Professor \\ ${ }^{1}$ Kyiv National University of Construction and Architecture, \\ 31, Povitroflotskiy avenu, Kyiv, Ukraine \\ ${ }^{2}$ Beijing International Education Institute, \\ 38 east 3rd ring north road, Chaoyang, Beijing, 100026, China \\ ${ }^{3}$ LLC 'SVK', 03049, Kyiv, Bogdanovskaya str., 7 V, Ukraine \\ DOI: $10.32347 / 2410-2547.2021 .107 .170-183$
}

The building patrimony of Ukraine includes various examples of metallic structures, especially applied for industrial purposes and in large-span structures. The use of metal structures in construction is due primarily to their mechanical properties. They are frost-resistant and able to withstand temperatures down to -65 degrees as well as they are hard, durable, strong and reliable. They can also be used in areas with high seismic activity. However, as in the case of other types of structures, there is a need to restore or strengthen metal structures due to structural defects, wear of load-bearing elements, as well as to increase the load-bearing capacity. In several situations, strengthening with Fiber Reinforced Polymer composites (FRP) gives better results. The current article deals specifically with this strengthening technique. The main cultural reason to restore the old metallic structures and provide a structural functionality, is based on the need to preserve not only their historical origins but also the scenery value of the places in which they are located. That is why the strengthening should be carried out with the aim of maintaining the original design idea.

Due to the long-term operation without timely maintenance and major repair, unique and metal large-span structures require strengthening of the load-bearing structures. It is especially important to choose the most efficient method, both in terms of reliability and cost effectiveness. This can lead to the long term interruption of the structure operation and production process, or the inability to use the adjacent territory due to the reconstruction work. At the same time, it is necessary to preserve not only the structure as a whole, but also the external architectural appearance.

Traditional methods of strengthening are effective, but in some cases not effective or not applicable for use. An example is the increase of the load-bearing structures of the buildings, preserving the external appearance of which is the determining factor. In this case, the use of the discussed methods can be justified alternative. Disadvantages of steel panels and rods for strengthening are possible corrosion, considerable weight, need for high labor content of the work, and consequently the high cost of labor required to perform the work that need large area.

Nowadays, one of the most dynamic types of large-span structures in architectural and structural view are suspension roofs. The aim of the research is the evaluation of the bearing capacity of the suspended rigid threads strengthened with CFRP (carbon fiber reinforced polymer) laminates and provision the general recommendations to implement reconstruction and strengthening with this type

(C) Rudnieva I., Priadko I., Tonkacheiev H., Priadko N. 
of material. Therefore it was considered variant of strengthening suspended bending-rigid fibers by composite materials. Computations are performed in software ABAQUS, as a result of which the percentage reduction in vertical deformation was $26.6 \%$ for bending-rigid fibers strengthened with CFRP laminates. The value of tensile stresses reduced by about $14 \%$.

The obtained results of the study confirm the need for further studies and research.

Keywords: methods of strengthening, FRP material, metal structures, suspended rigid threads, stress-strain state, computational methods. composite materials, reinforcement, defects, damage, reconstruction, bearing capacity.

Introduction. Nowadays, Ukrainian building patrimony includes various examples of metallic structures, especially applied for industrial purposes and in large-span structures. The use of metal structures in construction is due primarily to their mechanical properties. They are frost-resistant and able to withstand temperatures down to -65 degrees as well as they are hard, durable, strong and reliable. They can also be used in areas with high seismic activity. However, as in the case of other types of structures, there is a need to restore or strengthen metal structures due to structural defects, wear of load-bearing elements, as well as to increase the load-bearing capacity. At the same time, it is necessary to preserve not only the structure as a whole, but also the external architectural appearance.

The currently used traditional reinforcement methods to restore or increase the load-bearing capacity of metal structures are based on the use of steel plates by bolting and welding. They are very relevant and effective, but can not always be used in the case of reinforcement of load-bearing structures when the strengthening should be carried out with the aim of maintaining the original design idea. The disadvantages are that the steel plates increase the load on the structure and are prone to corrosion and fatigue as well as it is difficult to weld the reinforcing structure to the main structure. For example, in case when light weight and preservation of the appearance of spatial structures above the stands of stadiums is a determining factor, where a feeling of lightness is highly desirable.

In some cases, the costs associated with reinforcing an existing structure using external reinforcement with composite FRP materials are often less than those required for dismantling or renovating the building. This is not only from an economic and constructive, but also from a social point of view.

FRP can be applied to steel structures either by gluing composite sheets with a thermosetting resin or, it can be pre-stressed pultrusion laminates. Particular attention should be paid to the effectiveness of bonding techniques.

As for the choice of fiber, carbon is often the most suitable due to the higher value of the Young's modulus of elasticity than steel. Neither fiberglass nor aramid fibers have such qualities.

The purposes of strengthening metal structures with composite materials are to increase or restore the tensile strength, increase or restore the flexural strength, increase fatigue strength. Recent studies have also revealed the possibility of increasing or restoring the bearing capacity of thin compressed elements. However, the amount of both theoretical and experimental research is still not enough to determine a reliable design procedure. 
The use of FRP materials overcomes some of the difficulties associated with using traditional methods and materials for strengthening. FRP materials have much higher strength-to-weight ratio than steel $[18,19]$. They are much more resistant to corrosion and almost not exposed to it as well as extremely easy to use.

A significant effect of metal structures strengthening by external reinforcement with composite FRP-materials can be achieved by reinforcing the beams of industrial buildings or long-span structures. Such elements when reinforcing by traditional methods require complex design solutions, high labor costs, interruption of the production process to perform reinforcement work, as well as the weight of the reinforcing structure is often significant. Thus, the costs associated with strengthening the existing structure by external reinforcement with FRP-materials, both from an economic and social point of view, are often much lower than those required for dismantling or reconstruction of the structure.

To get a complete picture of a competent approach to provide the durability of such kind of structures as a result of computation, it is necessary to take into account an issue of structural reliability. This issue is so crucial since the study of limit states method has revealed that it does not provide required level of reliability for described kind of unique structures. At the same time, the recommended by regulations general measures to provide the structural reliability, in particular Eurocodes [8] (grading by consequences classes (CC) of structure, reliability classes (RC) etc.) do not always provide the required level of reliability $\beta_{i}^{e x}$ for structures with high consequence for loss of human life or economic, social or environmental consequences. Therefore, it is necessary to apply direct methods of the reliability theory.

2. Analysis of the latest achievements and publications. The main existing documents in the field of strengthening of metal structures by composite materials including recommendations of computation and design are:

- Eurocode 8 - Design of structures for earthquake resistance Part 3: Assessment and retrofitting of buildings. EN 1998-3:2004. European Committee for Standardisation (November 2004) [11].

- FIB bulletin 14. Externally bonded FRP reinforcement for RC structures. July 2001 [7].

- CNR-DT 202/2005 «Guidelines for the Design and Construction of Externally Bonded FRP Systems for Strengthening Existing Structures». Metallic structures. Preliminary study. ROME - CNR, 2007. 57 p. [5].

- ACI Committee 440 (2002) Guide for the design and construction of externally bonded FRP systems for strengthening concrete structures (ACI 440.2R-02). American Concrete Institute, Farmington Hills, MI, USA [6].

The relevant research in the world now focuses only on some special issues such as the reinforcement of stretched elements or reinforcement of stretched bending elements to reduce stresses in operation due to increased loads or corrosion $[1-4,17,23]$, as well as the strengthening of riveted elements to avoid the spread of fatigue cracks [35]. The effectiveness of using bonded 
CFRP sheets or plates to improve the fatigue strength has been examined by various researchers $[4,33,34]$. The features of fatigue strength of steel and CFRP adhesive bonds are presented in papers [35-38].

Great contribution to the theory of design with application of FRP-systems was made by G. Boscato [4], V. Zerbo and A. Di Tommaso [17]. However, indepth information on the nonlinear behavior of metal structures, in particular suspended structures of large span roofs reinforced with FRP, is still absent.

The reliability of metal structures in buildings and statically determined and non-determined systems have been investigated by several researchers, such as as G. Augusti, A. Baratt, V. Bolotin etc. Its major problems and some examples are described by Pichugin [43]. The reliability issue of suspension roofs was described by Priadko [33] but it doesn't consider the strengthening with FRP-materials.

3. Modeling of the suspended rigid threads. Nowadays, one of the most dynamic type of large-span structures in architectural and structural view are suspension roofs (Fig.1 and Fig. 2). The aim of the research is the evaluation of the bearing capacity of the suspended rigid threads strengthened with CFRP laminates.

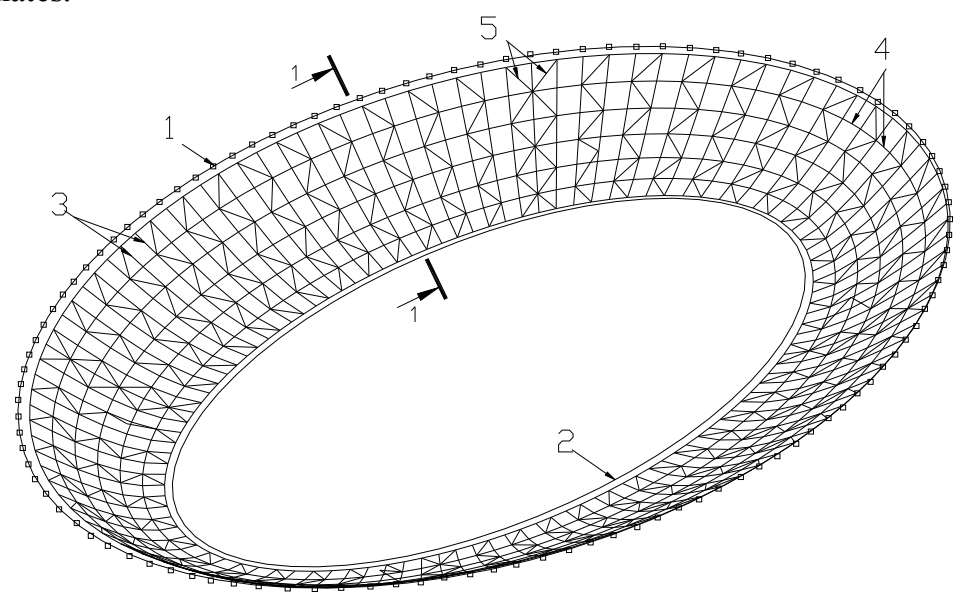

Fig.1. Structural schematic drawing of spatial and rod suspension roof:

1,2 - external and internal contours, 3, 4, 5 - radial, annular and diagonal components

Thus, taking into account the above advantages of FRP-materials, the option of strengthening the suspended steel structure by external reinforcement with gluing a high-strength fiber-reinforced carbon-based system was considered in current research. The model of the suspension roof was created in AutoCad. The obtained scheme was transferred to the software ABAQUS / CAE to carry out the macro analysis and determine the internal forces and deformations in structural elements. At the same time, 3D-models of roof joints (microanalysis) were made in SolidWorks and transferred to ABAQUS. Thereafter, the calculations of the model based on the finite element method were performed in a software ABAQUS. 


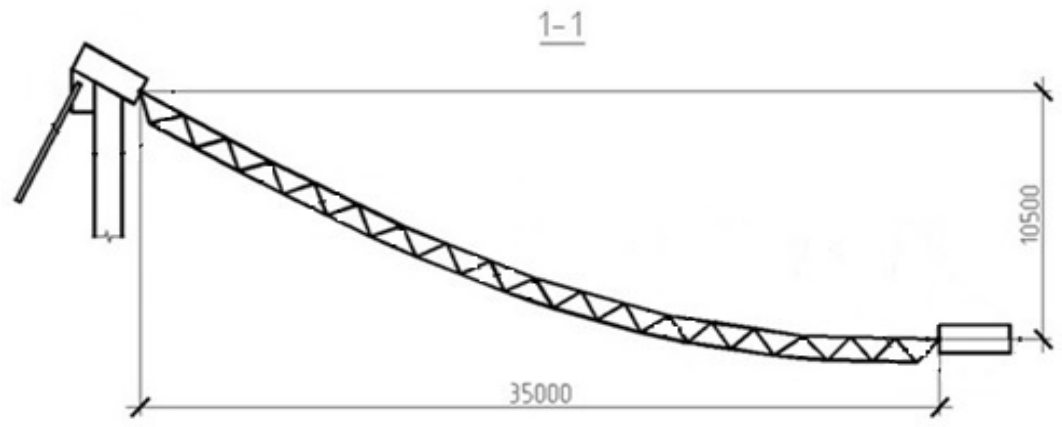

Fig. 2. Structural schematic drawing of spatial and rod roof. Open-cut mine 1-1

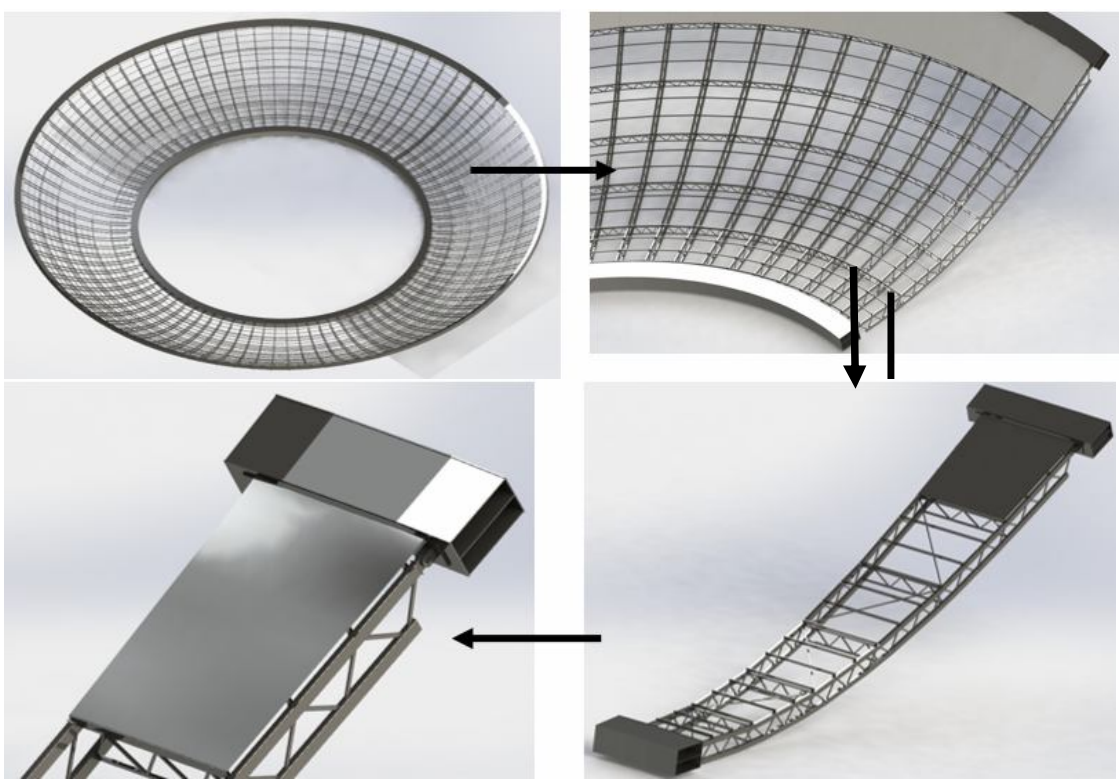

Fig.3. Suspension roof of the stadium with a cut on the elliptic plan.(transition from the rod scheme to 3D model)

A new roof was designed using standard football stadium roof dimensions (Fig.1 and Fig. 2). The main load-supporting elements of the roof are external contour, supported by stadium columns or walls; internal unsupported contour supported by thrust; rigid threads with a truss form (Fig. 3). The roof contours are designed by welded box-section from steel sheet. All the other elements of the supporting structure made by box-shaped profile. Two types of design load were considered: a constant load (structure weight) and a temporary load (snow), which is $160 \mathrm{~kg} / \mathrm{m}^{2}$. As shown in Fig. 2, the external contour is fixed along its length, though the internal contour is not fixed and is only supported by the thrust. 
4. Stress and strain state computations. Computations of the suspended rigid threads are performed in software ABAQUS. The modeling is shown on Fig. 3 - 4 .

The biggest stresses and strains in the suspended rigid threads appear in the area close to the external supporting contour. Thus, it was decided to consider stress and strain state of the suspended rigid threads in this zone before strengthening by CFRP and after strengthening by CFRP (Fig. $4-6$ ).

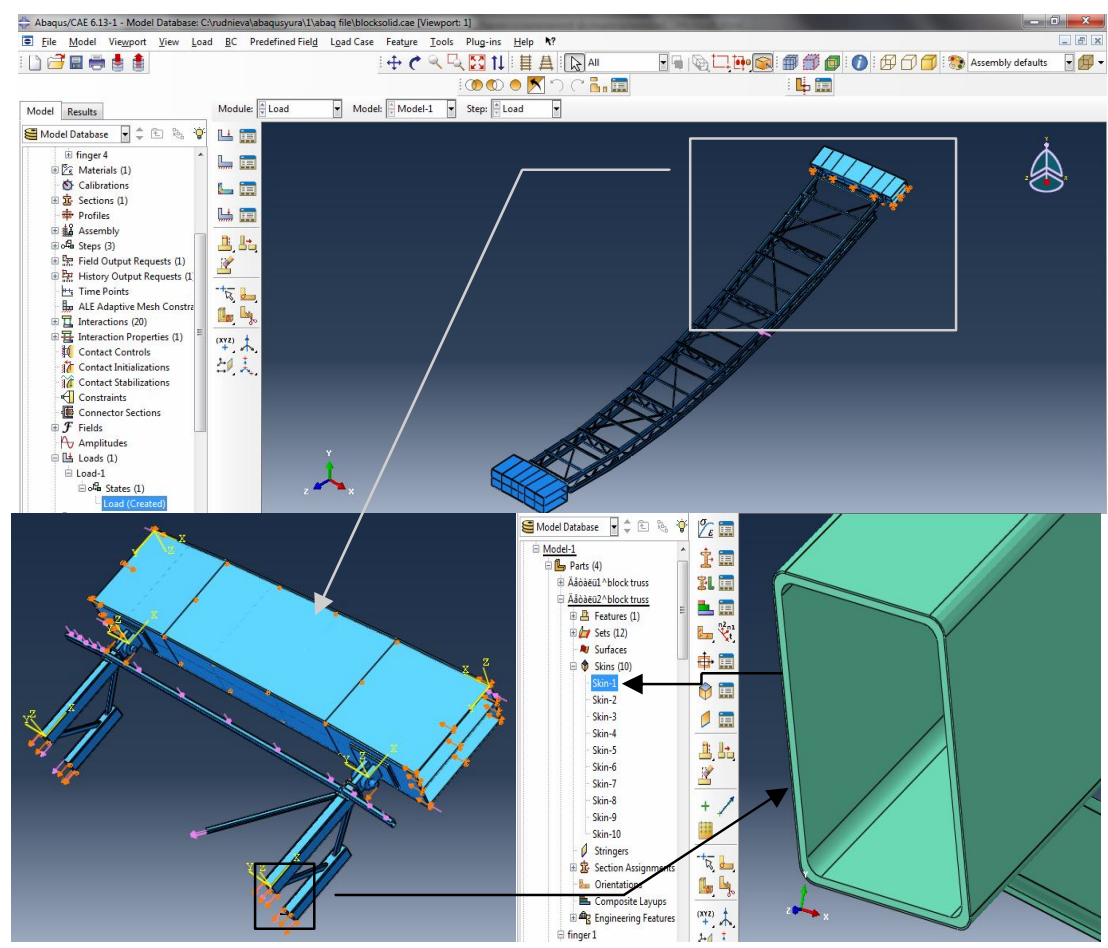

Fig. 4. Modeling and loading of the bending-rigid threads of a through section strengthened by CFRP in software ABAQUS

Looking at the Fig. 5 and 6 it might be concluded that after the strengthening by CFRP laminates, decrease of the vertical deformations was $26,6 \%$ as well as the value of tensile stresses was reduced by about $14 \%$.

5. Reliability issue. In engineering, the reliability evaluation of complex systems is usually concerned with the examination and analysis of two principal kinds of joints:

a) series connection, failure-free work probability of which at independent components is determined as:

$$
P_{m}=\prod_{i=1}^{m} P_{i},
$$

where $P_{i}$ is probability of failure-free work of $i$-component; 


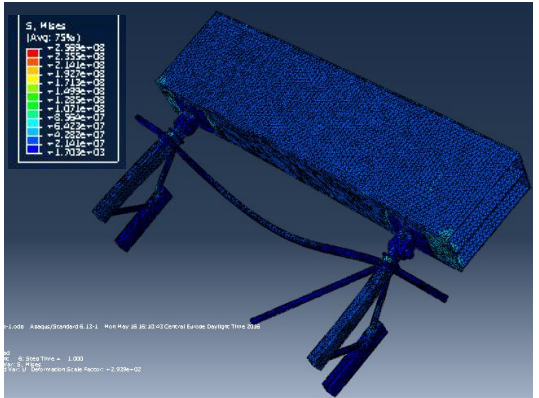

(a)

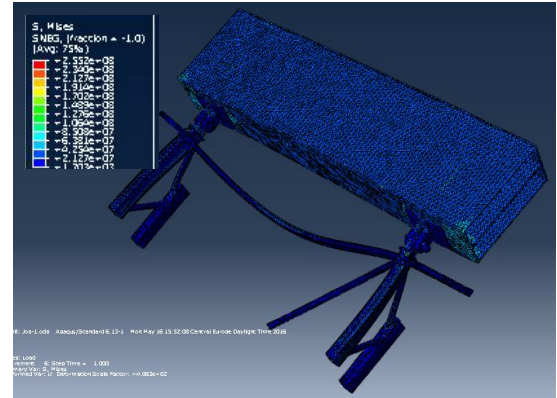

(b)

Fig. 5. Results of computation of the suspended bending-rigid fibers in software ABAQUS (stress): (a) before strengthening by CFRP; (b) after strengthening by CFRP

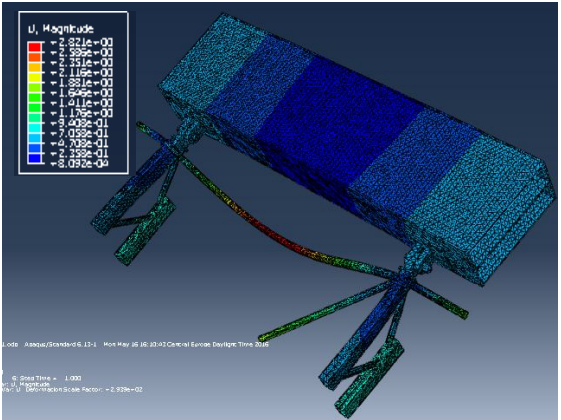

(a)

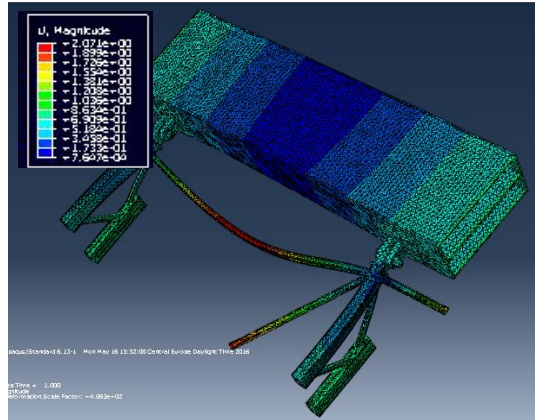

(b)

Fig. 6. Results of computation of the suspended bending-rigid fibers in software ABAQUS (magnitude): (a) before strengthening by CFRP; (b) after strengthening by CFRP

b) parallel connection

$$
P_{m}=1-\prod_{i=1}^{m}\left(1-P_{i}\right) \text {. }
$$

Series connection in probabilistic sense can be used to describe statically determined systems, e.g. trusses, though a practical evaluation of real structures reliability cannot be reduced to the application of a simple equation (1) due to the correlation between resistance indices of components.

The activities of statically non-determined systems is definitely associated with parallel connections, but the evaluation of its reliability cannot be defined by (2), because of the redistribution of forces in the system after the failure of separate components, which are dependent. Thus, the reliability evaluation of statically non-determined structures requires a thorough and careful analysis of the stress-stained state and failure under load, and also considering distinct features of component failures and the system as a whole.

The method described in [32] solves this issue and takes into account an individual approach while ensuring the required level of reliability of the building structure. The described method is devised for the static steel 
cantilever frame structures of roofs above the stadium stands. However, it might be applied to other spatial steel rod structures whose elements work as trusses, i.e. the system described in the current article. The internal force factor in the elements of such structures is the longitudinal force.

On the results of the computations performed according to the abovedescribed method, the values of the safety factor $\gamma_{\mathrm{c}}$ and the reliability index $\beta$ (failure range) might be obtained.

The safety factor $\gamma_{c}$ [12] is proposed to be calculated as follows [43]:

$$
\gamma_{c}=1-\frac{\gamma_{m}\left(\frac{\bar{\sigma}^{p}}{1-\mu_{\sigma} k_{\sigma}}-\sigma_{0}^{p}\right)}{\bar{R}_{y}^{n}\left(1-\mu_{r} k_{r}\right)},
$$

where: $\gamma_{m}$ - material reliability factor; $\bar{\sigma}^{p}$ - standard deviation of stresses arising in the considered structural element; $\mu_{\sigma}, \mu_{r}$ - mathematical expectation of the stress values in the considered structural element and the mathematical expectation of a random variable of the material strength (the yield strength); $k_{\sigma}, k_{r}$ - variation coefficients of two considered random variables; $\bar{R}_{y}^{n}$ - the standard value of the designed material strength of construction; $\sigma_{0}^{p}$ - the designed value of the stresses in the element obtained by ordinary deterministic design calculation.

Reliability index $\beta$ calculation:

$$
\beta=\frac{\tilde{R}-\tilde{Q}}{\sqrt{S_{R}^{2}+S_{Q}^{2}}},
$$

where: $S_{R}$ - standard deviation of the random variable of material yield strength; $S_{Q}$ - standard deviation of the random variable of stresses in the structural elements; $\tilde{R}$ - mathematical expectation of the random variable of material yield strength; $Q$ - mathematical expectation of the random variable of stresses in the structural elements;

The obtained values of $\gamma_{c}$ and $\beta$ must be compared with the regulatory ones $[8,12,45,46]$. If the results are inconsistent, the FRP cross-section is corrected [5].

6. Proposed recommendations. Despite the large amount of information about FRP-materials, questions of alternative methods for structural strengthening by FRP-materials and provision of its reliability remain unexplored. In addition, durability requirements, adaptability to manufacture, economic efficiency, ecological and social factors should be fulfilled in total volume.

Based on the above, we can recommend the following:

- preliminary computation in software based on finite element method;

- analysis of survivability;

- designing by the requirements of method of limit states; 
- design based on evaluating the reliability and durability of various ways of strengthening in various cases, available to designers.

7. Conclusion. This article attempts to review recent issues and developments in structural reinforcement using FRP materials and provides a general approach for implementing reconstruction and reinforcement with this type of material.

On the results of theoretical research, it was established that after the strengthening by CFRP laminates, decrease of the vertical deformations was $26,6 \%$ as well as the value of tensile stresses was reduced by about $14 \%$.

It is possible to increase the reliability of the structure by using the FRP materials in strengthening the tensioned elements.

The suspended rigid threads strengthened with CFRP laminates show enhanced ductility.

The main principle of placement of composite laminates, grids, rods consists in a parallel arrangement to tensile stresses.

The use of such FRP-materials for strengthening metal structures is not developed as for concrete, reinforced concrete, brick and masonry.

Currently, there is practically no scientific literature on experimental and analytical studies of the behavior of metal building structures, in particular, supporting metal elements of the through-section strengthened by external reinforcement using high-strength fiber-reinforced polymer systems. The existing guidelines for the design and strengthening of metal structures using FRP materials can only be applied to bending members that are tensilereinforced at the beams bottom and are based on the hypothesis of linear elastic behavior of steel.

This paper proposes a method based on the compatibility of deformations to determine the stress-strain state of the strengthened supporting metal elements of the through-section of suspended rod shell by external reinforcement using highstrength fiber-reinforced polymer systems. The proposed method is general and can be used to determine the stress-strain state of steel elements strengthened by carbon FRP (provided that steel and FRP material are rigidly connected), taking into account material nonlinearities and with any type of geometry of the original structure and reinforcement elements.

\section{REFERENCES}

1. Luke, S. \& Mouchel Consulting. The Use of Carbon Fibre Plates for the Strengthening of Two Metallic Bridges of a Historie Nature in the UK. In IG. Teng (ed.), FRP Composites in Civil Engineering, Vol. II.

2. Ceriolo, L. \& Di Tommaso, A. 2001. Cast Iron Bridge Failure Due to Impact: reduced Vulnerability thcough FRP Composite MateriaIs Strengthening. In National Con! on Structure failures and reliability of civil constructions; Proc. symp., Istituto Universitario di Architettura di Venezia, 6-7 December 2001.

3. Miller, T.e., Chajes, M.J" Mertz, D.R. \& Hastyings, J. 2001. Strengthening of a Steel Bridge Girder Using CFRP Plates, Journal of bridge engineering, ASCE, 6(6): from 514-522,

4. Giosuè Boscato. Numerical analysis and experimental tests on dynamic behaviour of GFRP pultruded elements for conservation of the architectural and environmental heritage. PhD. Dissertation. University Iuav of Venice, Venice, Italy, 2009. P 215.

5. CNR-DT 202/2005 «Guidelines for the Design and Construction of Externally Bonded FRP 
Systems for Strengthening Existing Structures. Metallic structures. Preliminary study». ROME CNR, 2007. $57 \mathrm{p}$.

6. ACI Committee 440 (2002) Guide for the design and construction of externally bonded FRP systems for strengthening concrete structures (ACI 440.2R-02). American Concrete Institute, Farmington Hills, MI, USA.

7. FIB bulletin 14 . Externally bonded FRP reinforcement for RC structures. July 2001

8. EN1990 Eurocode 0: Basis of structural design: EN 1990:2002+A1. [European Standard]. Brussels: Management Centre, 2002. 116 p.

9. EN1991 Eurocode 1: Actions on structures.

10. EN 1993 Eurocode 3: Design of steel structures.

11. Eurocode 8 - Design of structures for earthquake resistance Part 3: Assessment and retrofitting of buildings. EN 1998-3:2004. European Committee for Standardisation (November 2004)

12. DBN V.1.2-14:2018. Zahalni pryntsypy zabespechennia nadiinosti ta konstruktyv-noi bezpeky budivel, sporud, budivelnykh konstruktsii ta osnov. (General principles of ensuring the reliability and structural safety of buildings, structures, building structures and foundations) / Minrehionbud Ukrainy. - K.: DP «Ukrarkhbudinform», 2018. [in Ukrainian].

13. DBN V.1.2-2:2006. Navantazhennia i vplyvy. Normy proektuvannia. (Loads and influences. Design standards) / Minbudarkhitektury Ukrainy. - K.: Stal, 2006. [in Ukrainian].

14. DBN V.2.6-198:2014. Stalevi konstruktsii. Normy proektuvannia. (Steel structures. Design standards.) / Minrehion Ukrainy. - K.: DP «Ukrarkhbudinform», 2014. [in Ukrainian].

15. DBN A.1.1-94:2010. Proektuvannia budivelnykh konstruktsii za Yevrokodamy. Osnovni polozhennia. (Design of building structures according to Eurocode. Basic Provisions.) / Minrehionbud Ukrainy. - K.: DP «Ukrarkhbudinform», 2012. [in Ukrainian].

16. DSTU B V.1.2.-3:2006. Prohyny i peremishchennia. Vymohy proektuvannia. (Deflections and displacements. Design requirements.) /Minbud Ukrainy. - K.: Stal, 2006. [in Ukrainian].

17. V. Zerbo, A. Di Tommaso \& L. Ceriolo. FRP strengthening systems for metallic structures: a state ofthe art. Structural Analysis of Historical Constructions - Modena, Lourenço \& Roca (eds), 2005. Taylor \& Francis Group, London, ISBN 0415363799. http://www.hms.civil.uminho.pt/sahc/2004/891.pdf

18. I. Rudnieva, Yu. Priadko, M. Priadko, H. Tonkacheiev. Osoblyvosti ta perspektyvy vykorystannia tekhnolohii pidsylennia budivelnykh konstruktsii kompozytsinymy materialamy pry rekonstruktsii sporud (Features and prospects for the use of technologies for strengthening building structures with composite FRP-materials during reconstruction of buildings) / Zbirnyk naukovykh prats "BUDIVELNI KONSTRUKTsII. TEORIIA I PRAKTYKA". № 7 (2020), c.12-22. DOI: $10.32347 / 2522-4182.7 .2020 .12-22$ [in Ukrainian].

19. B. Täljsten, FRP strengthening of existing concrete structures - design guidelines (fourth edition), Luleå, Sweden: Luleå University of Technology; ISBN 91-89580-03-6, (2006)

20. Rudneva Y.N., Priadko Yu.N. Sravnytelnыi analyz Evrokodov y natsyonalnыkh standartov Ukraynы, $v$ tom chysle chastnukh koэffytsyentov nadezhnosty y ucheta faktora vremeny, pry proektyrovanyy konstruktsyi (Comparative analysis of Eurocodes and national standards of Ukraine, including partial reliability factors and taking into account the time factor in the design of structures) / Naukovo-vyrobnychyi zhurnal «Promyslove budivnytstvo ta inzhenerni sporudy», №1, 2020, str.39-45. http://nbuv.gov.ua/UJRN/Pbis_2020_1_10 [in Rusian].

21. M.V. Priadko, I.M. Rudnieva, Yu.M. Priadko. Obstezhennia ta pidsylennia budivelnykh konstruktsii promyslovykh budivel (Inspection and strengthening of building structures of industrial buildings) / Navchalnyi posibnyk. - Kyiv: KNUBA, 2018. - 332 s. [in Ukrainian].

22. I. Rudnieva, Yu. Priadko, M. Priadko. Analiz prychyn obvalennia pokrivel vyrobnychykh budivel. (Investigation of the roof collapse causes of industrial buildings.) / Zbirnyk naukovykh prats "Budivelni konstruktsii. Teoriia i praktyka". № 6 (2020), c.85-93. https://doi.org/10.32347/2522-4182.6.2020.85-93 [in Ukrainian].

23. Lanier, B.K. Study in the Improvement in Strength and Stiffness Capacity of Steel Multi- sided Monopole Towers Utilizing Carbon Fiber Reinforced Polymers as a Retrofitting Mechanism. M.S. Thesis, North Carolina State University, Raleigh, NC, 2005.

24. Cadei, J.M.C., Stratford T.J., Hollaway L.C., Duckett W.G. Strengthening metallic structures using externally bonded fibre-reinforced polymers, Report CIRIA C595. London: CIRIA. 2004.

25. Miller, T.C., Chajes, M.J., Mertz, D.R. and Hastyings, J. Strengthening of a Steel Bridge Girder Using CFRP Plates, Journal of bridge engineering, ASCE, 2001. 6(6): p. 514-522.

26. DSTU B V.3.1-2:2016. Remont i pidsylennia nesuchykh i ohorodzhuvalnykh budivelnykh konstruktsii ta osnov budivel i sporud (Repair and strengthening of load-bearing and enclosing building structures and foundations of buildings and structures). - Kyiv, 2017. - 68s. [in 
Ukrainian].

27. Posobye po obsledovanyiu stroytelnukh konstruktsyi zdanyi (Manual for the survey of building structures of buildings). AO TsNYYPromzdanyi. - M.: 1997.- 141s. [in Rusian].

28. DSTU-N B V.1.2-18:2016 Nastanova shchodo obstezhennia budivel i sporud dlia vyznachennia ta otsinky yikh tekhnichnoho stanu. (Guidelines for the survey of buildings and structures for the determination and assessment of their technical condition.) - Kyiv: DP «UkrNDNTs», 2017. 44 s. [in Ukrainian].

29. UNI EN 473:2008-11. Non-destructive testing - Qualification and certification of NDT personnel - General principles.

30. UNI CEI EN 45013:1990. General criteria for certification bodies operating certification of personnel.

31. Rudneva Y.N. 2006. Osobennosty prostranstvennoi rabotы vysiacheho pokrыtyia, obrazovannoho systemoi zhestkykh nytei (Behavior features of spatial work of suspended rod shell by system of bending-rigid fibers). Dys. kand. tekhn. nauk: 05.23.01 / Donbacskaia natsyonalnaia akademyia stroytelstva y arkhytekturb. Makeevka, 263 s. [in Rusian].

32. Orzhekhovskiy A., Priadko I., Tanasoglo A, Fomenko S. Design of stadium roofs with a given level of reliability. Engineering Structures. 2020. No. 209.

33. I.N. Priadko, I.N. Rudnieva,Y. Ribakov, H. Bartolo. A new approach to the design of suspension roof systems. «Strength of Materials and Theory of Structures». «Strength of Materials and Theory of Structures», 2020. № 104 - p.191-220. DOI: https://doi.org/10.32347/24102547.2020.104.191-220.

34. Amr Shaat, David Schnerch, Amir Fam, And Sami Rizkalla. Retrofit of steel structures using fiber reinforced polymers (frp). State-of-the-art, 2003.

35. A. Shaat And A. Fam. Control of overall buckling of hss slender steel columns using CFRP plates. Asia-pacific Conference on FRP in Structures (APFIS 2007). International Institute for FRP in Construction.

36. Bassetti, A., Nussbaumer, A., Hirt, M. 2000. Crack Repair and Fatigue Life Extension of Riveted Bridge Members using Composite Materials. In Proc., Bridge Engineering Conference, ESE-IABSE-FIB, 26-30 March 2000, Sharm El Sheik (Egypt).

37. Jones, S.C. and Civjan, S.A. (2003), "Application of Fiber Reinforced Polymer Overlays to Extend to Steel Fatigue Life," ASCE Journal of Composites for Construction, 7, pp. 331-338.

38. Miller, T.C. (2000), "The Rehabilitation of Steel Bridge Girders Using Advanced Composite Materials", M.S. Thesis, University of Delaware, Newark, DE, 58-79.

39. Tavakkolizadeh, M., and Saadatmanesh, H. 2003. Fatigue Strength of Steel Girders Strengthened With Carbon Fiber Reinforced Polymer Patch, Journal of Structural Engineering, ASCE, 2(129): from 186-196.

40. Priadko I.N., Mushchanov V.P., Bartolo E., Vatin N.I., Rudnieva I.N. Improved numerical methods in reliability analysis of suspension roof joints. Magazine of Civil Engineering. 2016. No. 5. Pp. 27-41. DOI: 10.5862/MCE.65.3.

41. V. P. Mushchanov, I. M. Rudnieva, Yu. M. Priadko. Napruzheno-deformovanyi stan vysiachoi systemy, utvorenoi systemoiu zghynalno-zhorstkykh nytok, z urakhuvanniam podatlyvosti opor (Intense-deformed condition of suspended system of bending-rigid fibers at the account of pliability of supports) / Zhurnal «Metallycheskye konstruktsyy». - T. 18. - № 1. Makiivka, 2012. - S. 5-16. https://www.elibrary.ru/item.asp?id=17784156 [in Ukrainian].

42. Mushchanov V.P., Rudneva I.N., Priadko Yu.M. Эksperymentalnoe yssledovanye bloka vysiachykh ferm prostranstvennoi sterzhnevoi obolochky (Experimental investigation of suspension trusses block of spacial rod-shaped covering) / Sb. nauchnыkh trudov «Sovremennыe stroytelnbe konstruktsyy yz metalla y drevesynы». - chast 1. Odessa: OHASA, 2005. - S. 138144. [in Rusian].

43. Pichugin S. F. Nadezhnost stalnyih konstruktsiy proizvodstvennyih zdaniy [Durability of steel structures of industrial buildings]. Poltava: ASV; 2011. [in Rusian].

44. I.N. Rudnieva. Comparative analysis of strengthening of building structures (masonry, metal structures, reinforced concrete) using FRP-materials and traditional methods during reconstruction. «Strength of Materials and Theory of Structures», 2020. № $105-$ p.267291. https://doi.org/10.32347/2410-2547.2020.105.267-291.

45. ISO 2394:2015. International standard. General principles on reliability for structures. ISO 2015. Pages 112.

46. Risk assessment in engineering. Principles, system representation and risk criteria. JCSS - Joint Committee on Structural Safety. Edited by M.H. Faber. - June 2008. Pages 35. 
Руднєва І., Прядко Ю., Тонкачеєв Г., Прядко М.

\section{ДОСЛІДЖЕННЯ ЕФЕКТИВНОСТІ ПІДСИЛЕННЯ МЕТАЛЕВИХ ЕЛЕМЕНТІВ ВИСЯЧІХ ПОКРІВЕЛЬ ЗА ДОПОМОГОЮ ФІБРОАРМОВАНИХ СИСТЕМ:} АНАЛІТИЧНИЙ ПІДХІД

Будівельна спадщина України включає в себе різні приклади металевих конструкцій, особливо тих, що використовуються в промислових цілях і в великопрольотних спорудах.

Застосування металевих конструкцій в будівництві зумовлене, перш за все, їх механічними властивостями. Вони морозостійкі і витримують температуру до -65 градусів, жорсткі, стійкі, міцні і надійні. Також їх можна використовувати в районах 3 підвищеною сейсмічною активністю. Але, як і у випадку з іншими типами конструкцій, існує необхідність у відновленні або підсиленні металевих конструкцій внаслідок конструктивних дефектів, зносу несучих елементів, а також з метою збільшення несучої здатності. У деяких випадках підсилення з застосуванням високоміцних фіброармованих систем дає кращі результати, ніж традиційні методи підсилення. Ця стаття присвячена саме цій техніці підсилення. Основна культурна причина відновлення старих металевих конструкцій, які гарантують конструктивну функціональність та несучу здатність, заснована не тільки на необхідності збереження іх історичного походження, а й на цінності ландшафту, в яких вони розташовані. 3 цих причин підсилення повинно проводитися з метою збереження первісної дизайнерської ідеї.

Унікальні і великопрольотні споруди, які проектуються з металу, в результаті тривалої експлуатації, без своєчасного технічного обслуговування та капітальних ремонтів, недостатньої міцність матеріалів конструкцій, зокрема, що мають елементи, що працюють на згин, потребують підсилення несучих конструкцій в результаті конструктивних дефектів, зносу, для збільшення несучої здатності в результаті зміни погодних умов та діючих нормативних документів в Україні, підвищення надійності, продовження їх експлуатації тощо. Особливо важливим $є$ вибір максимально ефективного методу, як з точки зору надійності, так i 3 точки зору рентабельності, на що впливає тривале припинення експлуатації споруди, зупинка виробничого процесу або неможливість користуватися прилеглою територією для виконання робіт з реконструкції. При цьому необхідно зберегти не тільки будівлю в цілому, але і зовнішній архітектурний вигляд споруди.

Традиційні методи підсилення дієві, але в деяких випадках неефективні. Прикладом може служити збільшення розмірів несучих конструкцій будівель, збереження зовнішнього вигляду яких $\epsilon$ визначальним фактором. Недоліками використання сталевих пластин та стрижнів для підсилення є можлива корозія, вони мають значну вагу, а також, для монтажу сталевих елементів потрібна велика трудомісткість, а отже, і висока вартість монтажу.

Сьогодні одним із найдинамічніших видів великопрольотних конструкцій в архітектурному і конструктивному відношенні $є$ підвісні покрівлі. Метою дослідження $є$ оцінка несучої здатності висячих згинально-жорстких ниток, підсилених високоміцними фіброармованими системами на основі углероду, та надання загальних рекомендацій щодо проведення реконструкції та підсилення цим видом матеріалу. Тому було розглянуто варіант підсилення висячих згинально-жорстких ниток композитними матеріалами. Розрахунки, виконані в сучасному програмному комплексі ABAQUS/CAE, заснованому на методі скінченних елементів, показали, що після включення в роботу вуглепластики відсоткове зменшення вертикального прогину склало $26,6 \%$ для згинально-жорстких ниток, підсилених композитним матеріалом 3 вуглепластики. Величина розтягуючих напружень знизилась приблизно на $14 \%$.

Отримані результати дослідження підтверджують необхідність подальших досліджень.

Ключові слова: методи підсилення, фіброармовані системи, металеві конструкції, висячі згинально-жорсткі нитки, напружено-деформований стан, методи розрахунку, композитні матеріали, армований волокном полімер FRP, дефекти, пошкодження, реконструкція, несуча здатність.

Rudnieva I., Priadko I., Tonkacheiev H., Priadko N.

INVESTIGATION OF THE EFFECTIVENESS OF STRENGTHENING WITH FRP APPLIED IN METAL ELEMENTS OF SUSPENSION ROOF: AN ANALYTICAL APPROACH

The building patrimony of Ukraine includes various examples of metallic structures, especially applied for industrial purposes and in large-span structures. The use of metal structures in construction is due primarily to their mechanical properties. They are frost-resistant and able to withstand temperatures down to -65 degrees as well as they are hard, durable, strong and reliable. 
They can also be used in areas with high seismic activity. However, as in the case of other types of structures, there is a need to restore or strengthen metal structures due to structural defects, wear of load-bearing elements, as well as to increase the load-bearing capacity. In several situations, strengthening with Fiber Reinforced Polymer composites (FRP) gives better results. The current article deals specifically with this strengthening technique. The main cultural reason to restore the old metallic structures and provide a structural functionality, is based on the need to preserve not only their historical origins but also the scenery value of the places in which they are located. That is why the strengthening should be carried out with the aim of maintaining the original design idea.

Due to the long-term operation without timely maintenance and major repair, unique and metal large-span structures require strengthening of the load-bearing structures. It is especially important to choose the most efficient method, both in terms of reliability and cost effectiveness. This can lead to the long term interruption of the structure operation and production process, or the inability to use the adjacent territory due to the reconstruction work. At the same time, it is necessary to preserve not only the structure as a whole, but also the external architectural appearance.

Traditional methods of strengthening are effective, but in some cases not effective or not applicable for use. An example is the increase of the load-bearing structures of the buildings, preserving the external appearance of which is the determining factor. In this case, the use of the discussed methods can be justified alternative. Disadvantages of steel panels and rods for strengthening are possible corrosion, considerable weight, need for high labor content of the work, and consequently the high cost of labor required to perform the work that need large area.

Nowadays, one of the most dynamic types of large-span structures in architectural and structural view are suspension roofs. The aim of the research is the evaluation of the bearing capacity of the suspended rigid threads strengthened with CFRP (carbon fiber reinforced polymer) laminates and provision the general recommendations to implement reconstruction and strengthening with this type of material. Therefore it was considered variant of strengthening suspended bending-rigid fibers by composite materials. Computations are performed in software ABAQUS, as a result of which the percentage reduction in vertical deformation was $26.6 \%$ for bending-rigid fibers strengthened with CFRP laminates. The value of tensile stresses reduced by about $14 \%$.

The obtained results of the study confirm the need for further studies and research.

Keywords: methods of strengthening, FRP material, metal structures, suspended rigid threads, stress-strain state, computational methods, composite materials, reinforcement, defects, damage, reconstruction, bearing capacity.

УДК 624.016:69.059:624.014:69.05

Руднєва І., Прядко Ю., Тонкачеєв Г., Прядко М.

Дослідження ефективності підсилення металевих елементів висячих покрівель за допомогою фіброармованих систем: аналітичний підхід // Опір матеріалів і теорія споруд: наук.-тех. збірн. - К.: КНУБА, 2021. - Вип. 107. - С. 170-183. - Англ.

Табл. 0. Іл. 6. Бібліогр. 46 назв.

UDC 624.016:69.059:624.014:69.05

Rudnieva I., Priadko I., Tonkacheiev H., Priadko N. Investigation of the effectiveness of strengthening with FRP applied in metal elements of suspension roof: an analytical approach // Strength of Materials and Theory of Structures: Scientific-and-technical collected articles. - K.: KNUBA, 2021. - Issue 107. - P. 170-183.

Tabl. 0. Fig. 6. Ref. 46.

УДК 624.016:69.059:624.014:69.05

Руднева И., Прядко Ю., Тонкачеєв Г., Прядко Н. Исследования эффективности усиления металлических элементов висячих покрытий с помощью фиброармованих систем: аналитический подход // Сопротивление материалов и теория сооружений: науч.-тех. сборн. - К.: КНУСА, 2021. - Вип. 107. - С. 170-183. - Англ.

Табл. 0. Ил. 6. Библиогр. 46 назв. 
Автор (науковий ступінь, вчене звання, посада): кандидат технічних наук, доцент кафедри опору матеріалів КНУБА РУДНСВА Ірина Миколаївна.

Адреса: 03680 Украӥна, м. Київ, Повітрофлотський проспект 31, КНУБА, кафедра опору матеріалів, Руднєва Ірина Миколаӥвна.

Робочий тел.: +38(044) 241-54-21;

Мобільний тел.: +38(050) 620-32-31;

E-mail: irene_r@ukr.net

ORCID ID: http://orcid.org/0000-0002-9711-042X

Автор (науковий ступінь, вчене звання, посада): кандидат технічних наук, науковий співробітник, доцент у BEIJING INTERNATIONAL EDUCATION INSTITUTE (BIEI - КИTAЙ) ПРЯДКО Юрій Миколайович.

Адреса: BIEI Beijing , 3708, SOHO Nexus Center, No. 19A East 3rd Ring Road North, Chaoyang District, Beijing, Beijing 100027, CN, Iurii Priadko.

Робочий тел.: +86 153-721-881-15;

Мобільний тел.: +38(066) 184-29-51;

E-mail: y.n.pryadko@ukr.net

ORCID ID: https://orcid.org/0000-0001-7163-4295

Автор (науковийступінь, вчене звання, посада): доктор технічних наук, професор кафедри будівельних технологій, проректор з навчально-методичної роботи КНУБА, ТОНКАЧЕСВ Геннадій Миколайович

Адреса: 03680 Украӥна, м. Київ, Повітрофлотський проспект 31, КНУБА, кафедра будівельних технологій, Тонкачеєв Геннадій Миколайович

Робочий тел.: +38(044) 243-26-03;

Мобільний тел.: +38(050) 922-84-13;

E-mail: tonkacheyev@gmail.com

ORCID ID: https://orcid.org/0000-0002-6589-8822

Автор (науковийступінь, вчене звання, посада): кандидат технічних наук, доцент, керівник ООО “СВК” ПРЯДКО Микола Володимирович.

Адреса ООО “СВК”, 03049, Україна, м. Київ, вул. Богданівська., 7в, Ukraine, ПРЯДКО Микола Володимирович.

Робочий тел.: +38050-529-30-53;

Мобільний тел.: +38050-759-50-90;

E-mail: pryadko_nv@ukr.net

ORCID ID: http://orcid.org/0000-0002-2934-9770 